\section{Nutrient Disorders of 'Evolution' Mealy-cup Sage}

\author{
Jared Barnes ${ }^{1,3}$, Brian Whipker ${ }^{1}$, Ingram McCall ${ }^{1}$, \\ and Jonathan Frantz ${ }^{2}$
}

ADDITIONAL INDEX WORDs. deficiency, macronutrients, micronutrients, Salvia farinacea, toxicity

Summary. To produce floriculture crops like mealy-cup sage (Salvia farinacea), growers must be equipped with cultural information including the ability to recognize and characterize nutrient disorders. 'Evolution' mealy-cup sage plants were grown in silica-sand culture to induce, describe, and photograph symptoms of nutritional disorders. Plants received a complete modified Hoagland's all-nitrate solution of (macronutrient concentrations in millimoles) 15 nitrate-nitrogen $(\mathrm{N})$, 1.0 phosphorus $(\mathrm{P}), 6.0$ potassium $(\mathrm{K}), \mathbf{5 . 0}$ calcium $(\mathrm{Ca}), 2.0$ magnesium $(\mathrm{Mg})$, and 2.0 sulfur $(S)$ plus (micronutrient concentrations in micromoles) 72 iron $(\mathrm{Fe}), 18$ manganese $(\mathrm{Mn}), 3$ copper $(\mathrm{Cu}), 3$ zinc $(\mathrm{Zn}), 45$ boron $(\mathrm{B})$, and 0.1 molybdenum (Mo). Nutrient-deficient treatments were induced with a complete nutrient formula minus one of the nutrients. The B-toxicity treatment was induced by increasing the element 10-fold higher than the complete nutrient formula. Reagent-grade chemicals and deionized (DI) water of 18 million ohms per centimeter purity were used to formulate treatment solutions. We monitored plants daily to document and photograph sequential series of symptoms as they developed. Typical symptomology of nutrient disorders and corresponding tissue concentrations were determined. Out of 13 treatments, 12 exhibited symptomology; Mo was asymptomatic. Symptoms of N, P, S, Ca, and K deficiencies and B toxicity manifested early; therefore, these disorders may be more likely problems encountered by growers. Unique symptoms were observed on plants grown under $\mathrm{N}_{-}, \mathrm{Cu}_{-}^{-}$, and $\mathrm{Zn}$-deficient conditions. Necrosis was a common symptom observed, but use of other diagnostic criteria about location on the plant and progression of the disorder can aid growers in diagnosing nutrient disorders of mealy-cup sage.

$\mathrm{E}$ ach essential element taken up by a plant serves to fulfill a specific physiological role, and reduced (nutrient deficiency) or excess (nutrient toxicity) levels of that element often result in unique symptomology that may be used for diagnostic purposes. The differences in the specificity of the roles and accompanying nutritional disorders are illustrated with $\mathrm{N}$ and $\mathrm{Ca}$ deficiencies. An important component of amino acids, proteins, and nucleic acids (Briskin and Bloom, 2010), $\mathrm{N}$ is able to be translocated to actively growing regions under $\mathrm{N}$-deficient conditions, and symptomology typically manifests in the lower leaves. On the other hand, $\mathrm{Ca}$, an important component of cell

We are grateful for the funding support provided by USDA-ARS and the Floriculture and Nursery Research Initiative, and we would like to thank Benary for the mealy-cup sage seed, and to Doug Sturtz, Russ Friedrich, and Alycia Pittenger for nutrient analysis.

${ }^{1}$ Department of Horticultural Science, North Carolina State University, Box 7609, Raleigh, NC, 27695

${ }^{2}$ U.S. Department of Agriculture, Agricultural Research Service, Application Technology Research Unit, 2801 W. Bancroft, MS 604, Toledo, OH 43606

${ }^{3}$ Corresponding author. E-mail: esculentus@gmail.com. walls, is much more immobile; thus, symptoms will typically appear in the upper foliage (Gibson et al., 2007). While it is true that across the spectrum of plant species many similarities exist in how each nutrient is used, not all species will develop symptomology, and some crops may actually manifest unique symptomology (Nelson, 2012). For example, Reuther and Labanauskas (1973) stated a speciesspecific approach is required to determine symptoms of $\mathrm{Cu}$ deficiency. To evaluate crops for the unique symptoms of species-specific disorders, it was important the plants be grown under nutrient-stress conditions to add this information to the grower's toolbox of diagnostic criterion. To quickly recognize and diagnose nutrient disorders, growers should have knowledge of symptoms and diagnostic tools. These diagnostic tools include symptomology descriptions, images of the disorders, and reference tissue concentrations.

Mealy-cup sage (Lamiaceae family) is a bedding annual planted by gardeners to provide color during the summer (Armitage, 2001). Few nutrient disorders have been reported for mealy-cup sage. Interveinal chlorosis was reported as a symptom for $\mathrm{Mg}$ deficiency (SePRO, 2000). Symptoms described for high electrical conductivity (EC) included necrotic foliage (Armitage et al., 1994) and leaf cupping (SePRO, 2000). Thick veins on young leaves with a gray or brown coloration was due to high salts or ammonium toxicity (Dreistadt, 2001; SePRO, 2000). Cool temperatures with reduced nutrition caused chlorosis (SePRO, 2000).

With the lack of knowledge of other nutritional problems that may occur with mealy-cup sage, growers may face plant loss, increased cost, and wasted time if a nutritional prob$\mathrm{lem}$ arises in the greenhouse. Therefore, the objectives for this research were to determine what nutrientdisorder symptoms occur in mealycup sage and to elucidate threshold nutrient levels.

\section{Materials and methods}

The experiment was conducted in a glass greenhouse in Raleigh, NC, at $35^{\circ} \mathrm{N}$ latitude. 'Evolution' mealycup sage plugs $(2.7 \times 2.7 \times 3.6 \mathrm{~cm}$ cell size; Raker, Litchfield, MI) were singly transplanted into 5 -inch-diameter (0.76 L vol.) plastic pots containing

\begin{tabular}{llll}
\hline $\begin{array}{l}\text { Units } \\
\begin{array}{l}\text { To convert U.S. to SI, } \\
\text { multiply by }\end{array}\end{array}$ & U.S. unit & SI unit & $\begin{array}{l}\text { To convert SI to U.S., } \\
\text { multiply by }\end{array}$ \\
\hline 29.5735 & $\mathrm{fl} \mathrm{oz}$ & $\mathrm{mL}$ & 0.0338 \\
0.3048 & $\mathrm{ft}$ & $\mathrm{m}$ & 3.2808 \\
3.7854 & gal & $\mathrm{L}$ & 0.2642 \\
2.54 & inch(es) & $\mathrm{cm}$ & 0.3937 \\
25.4 & inch(es) & $\mathrm{mm}$ & 0.0394 \\
28.3495 & $\mathrm{oz}$ & $\mathrm{g}$ & 0.0353 \\
28,350 & $\mathrm{oz}$ & $\mathrm{mg}$ & $3.5274 \times 10^{-5}$ \\
1 & $\mathrm{ppm}$ & $\mathrm{mg} \cdot \mathrm{kg}^{-1}$ & 1 \\
1 & $\mathrm{ppm}$ & $\mathrm{mg} \cdot \mathrm{L}^{-1}$ & 1 \\
$\left({ }^{\circ} \mathrm{F}-32\right) \div 1.8$ & ${ }^{\circ} \mathrm{F}$ & ${ }^{\circ} \mathrm{C}$ & $\left(1.8 \times{ }^{\circ} \mathrm{C}\right)+32$
\end{tabular}


acid-washed silica sand [Millersville \#2 (0.8-1.2 mm diameter); Southern Products and Silica Co., Hoffman, NC] on 11 June 2009. Seedlings were fertilized with each irrigation using $150 \mathrm{mg} \cdot \mathrm{L}^{-1} \mathrm{~N}$ from $13 \mathrm{~N}-$ 0.9P-10.8K Cal-Mag (SQM North America, Atlanta). Plants were grown with $70{ }^{\circ} \mathrm{F}$ day and $65^{\circ} \mathrm{F}$ night air temperature set points and ambient light and natural photoperiods. Because symptoms of $\mathrm{N}, \mathrm{P}$, and $\mathrm{Fe}$ manifested too early to obtain adequate tissue, we grew additional plants in complete control and N-, P-, and Fe-deficient conditions to obtain adequate tissue with the following exceptions. 'Evolution' mealycup sage seeds were sown into a 72 -plug $(4.0 \times 4.0 \times 5.8 \mathrm{~cm}$ cell dimensions) tray containing Fafard 4P (Conrad Fafard, Agawam, MA) root substrate. These plants were installed in the previously described manner on 9 Nov. 2009 into treatments for control, N-, P-, and Fedeficient conditions.

Treatments started immediately upon transplanting. An automated, recirculating irrigation system was constructed out of 4-inch-diameter PVC pipe [PVC (Charlotte Plastics, Charlotte, NC)]. The system consisted of 18 separate irrigation lines (each $6 \mathrm{ft}$ long). Each line contained eight openings on the top that contained PVC funnels with 5-inchdiameter openings that held the eight pots for the elemental treatment; 13 lines contained the disorder treatments and five lines contained the control treatments. Pipes were randomly assigned as a control or treatment after the system was constructed. Control plants were grown with a complete modified Hoagland's all-nitrate solution of (macronutrient concentrations in millimoles) $15 \mathrm{~N}, 1.0 \mathrm{P}, 6.0 \mathrm{~K}$, $5.0 \mathrm{Ca}, 2.0 \mathrm{Mg}$, and $2.0 \mathrm{~S}$ (Hoagland and Arnon, 1950) plus (micronutrient concentrations in micromoles) $72 \mathrm{Fe}, 18 \mathrm{Mn}, 3 \mathrm{Cu}, 3 \mathrm{Zn}, 45 \mathrm{~B}$, and 0.1 Mo. Reagent-grade chemicals and DI water of 18 million ohms per centimeter purity were used to formulate stock solutions (Table 1 ). Nutrients in the stock solutions originated from the salts of potassium nitrate $\left(\mathrm{KNO}_{3}\right)$, calcium nitrate tetrahydrate $\left[\mathrm{Ca}\left(\mathrm{NO}_{3}\right)_{2} \cdot 4 \mathrm{H}_{2} \mathrm{O}\right]$, potassium phosphate monobasic $\left(\mathrm{KH}_{2} \mathrm{PO}_{4}\right)$, magnesium sulfate heptahydrate $\left(\mathrm{MgSO}_{4} \cdot 7 \mathrm{H}_{2} \mathrm{O}\right)$, iron diethylenetriaminepentaacetic acid (FeDTPA), manganese chloride tetrahydrate $\left(\mathrm{MnCl}_{2} \cdot 4 \mathrm{H}_{2} \mathrm{O}\right)$, zinc chloride $\left(\mathrm{ZnCl}_{2}\right)$, cupric chloride dihydrate $\left(\mathrm{CuCl}_{2} \cdot \mathrm{H}_{2} \mathrm{O}\right)$, boric acid $\left(\mathrm{H}_{3} \mathrm{BO}_{3}\right)$, and sodium molybdate dihydrate $\left(\mathrm{Na}_{2} \mathrm{MoO}_{4} \cdot 2 \mathrm{H}_{2} \mathrm{O}\right)$. Sodium hydroxide $(\mathrm{NaOH})$ was added to adjust the pH to 6.0 (Barnes, 2010).

To induce nutrient-deficient treatments, the plants were irrigated with complete nutrient solution excluding one of the nutrients. For macronutrients, because many of the cations and anions listed above were linked to a corresponding required element, we used the salts potassium chloride $(\mathrm{KCl})$, calcium chloride dihydrate $\left(\mathrm{CaCl}_{2} \cdot 2 \mathrm{H}_{2} \mathrm{O}\right)$, sodium nitrate $\left(\mathrm{NaNO}_{3}\right)$, sodium phosphate monobasic monohydrate $\left(\mathrm{NaH}_{2}\right.$. $\mathrm{PO}_{4} \cdot \mathrm{H}_{2} \mathrm{O}$ ), sodium sulfate anhydrous $\left(\mathrm{Na}_{2} \mathrm{SO}_{4}\right)$, and magnesium chloride hexahydrate $\left(\mathrm{MgCl}_{2} \cdot 6 \mathrm{H}_{2} \mathrm{O}\right)$ in the stock solutions to supply the missing element. In each case for macronutrients, the salt cations were replaced with sodium $(\mathrm{Na})$, and anions were replaced with chloride $(\mathrm{Cl})$. For micronutrients, the micronutrient stock solution containing the micronutrient salt was omitted from the solution. The B-toxicity treatment was conducted by increasing B concentration to $450 \mu \mathrm{M}$ in the Hoagland's solution. Stock solutions were added to a 32 -gal barrel partially filled with DI water and then topped up to $100 \mathrm{~L}$ using DI water. Irrigation was automated using a drip system equipped with sump-pumps (model 1A; Little Giant Pump Co., Oklahoma City, OK) and plastic emitters, and the frequency was adjusted to maintain plant turgidity so that the plants never experienced wilting; on average, irrigation occurred once every $3 \mathrm{~h}$ from 0600 to 1800 HR. The solution drained out from the bottom of the pot into the PVC pipe and was captured for reuse. Nutrient solutions were replaced weekly. Plants were monitored daily to record the date symptoms manifested and to document and photograph sequential series of symptoms on youngest, young, recently mature, and/or mature leaves as they developed.

When the initial symptom occurred on the shoots of each treatment, the date was recorded and three potted plants were selected for sampling. The remaining five potted plants were grown to document advanced symptoms. Recently matured, fully expanded leaves were sampled to evaluate the threshold tissue concentration for each element. Harvested leaves were initially rinsed with DI water, then washed in a solution of $0.5 \mathrm{~N} \mathrm{HCl}$ for $1 \mathrm{~min}$ and again rinsed with DI water. The remaining shoot tissue was harvested separately. Roots were discarded. Both sets of tissue were dried at $70{ }^{\circ} \mathrm{C}$ for at least 1 week, and the dry weights were recorded (Table 2). After drying, fully expanded leaf tissue was ground in a sample mill (Foss Tecator Cyclotec ${ }^{\mathrm{TM}}$; Analytical Instruments, Golden Valley, $\mathrm{MN}$ ) to pass a $\leq 0.5-\mathrm{mm}$ sieve. Tissue analysis for $\mathrm{N}$ was performed with a C-H-N analyzer (model 2400 series II; PerkinElmer, Norwalk, CT) by weighing $3.5 \mathrm{mg}$ of dried tissue into tin cups and placing it into the analyzer. Other nutrient concentrations were determined with inductively coupled plasma optical emission spectroscopy [(ICP-OES (model IRIS Intrepid II; Thermo Corp., Waltham, $\mathrm{MA})$ ]. Tissue concentration values obtained from this experiment were compared with optimum values (Table 3 ) published by Mills and Jones (1996) for scarlet sage (Salvia splendens), another bedding sage (Dole and Wilkins, 2005). The first experiment for all treatments was ended on 28 July 2009. At termination any treatments that were symptomless were sampled for shoot dry weight and nutrient concentrations of the recently expanded mature leaves. Additional plants that were grown for obtaining adequate tissue in the complete control and under N-, P-, and Fedeficient conditions were ended on 17 Dec. 2009. All the data were subjected to analysis of variance (ANOVA) using PROC ANOVA of SAS (version 9.2; SAS Institute, Cary, NC). Where the $F$ test indicated evidence of significant difference among the means, least significant difference at $P \leq 0.05$ was used to establish differences between means.

\section{Results}

Out of 13 nutrient disorder treatments, 12 exhibited symptomology. Symptoms and shoot dry weight values (Table 2) were reported. Values for percentage difference in shoot dry weights were presented in the text if 
Table 1. Salts used to formulate stock fertilizer and base solutions, stock solution molarity, and volume of stock solutions used to prepare $100 \mathrm{~L}(26.4 \mathrm{gal})$ of nutrient solution for the mealy-cup sage complete control, nutrient deficiency treatments, and boron toxicity.

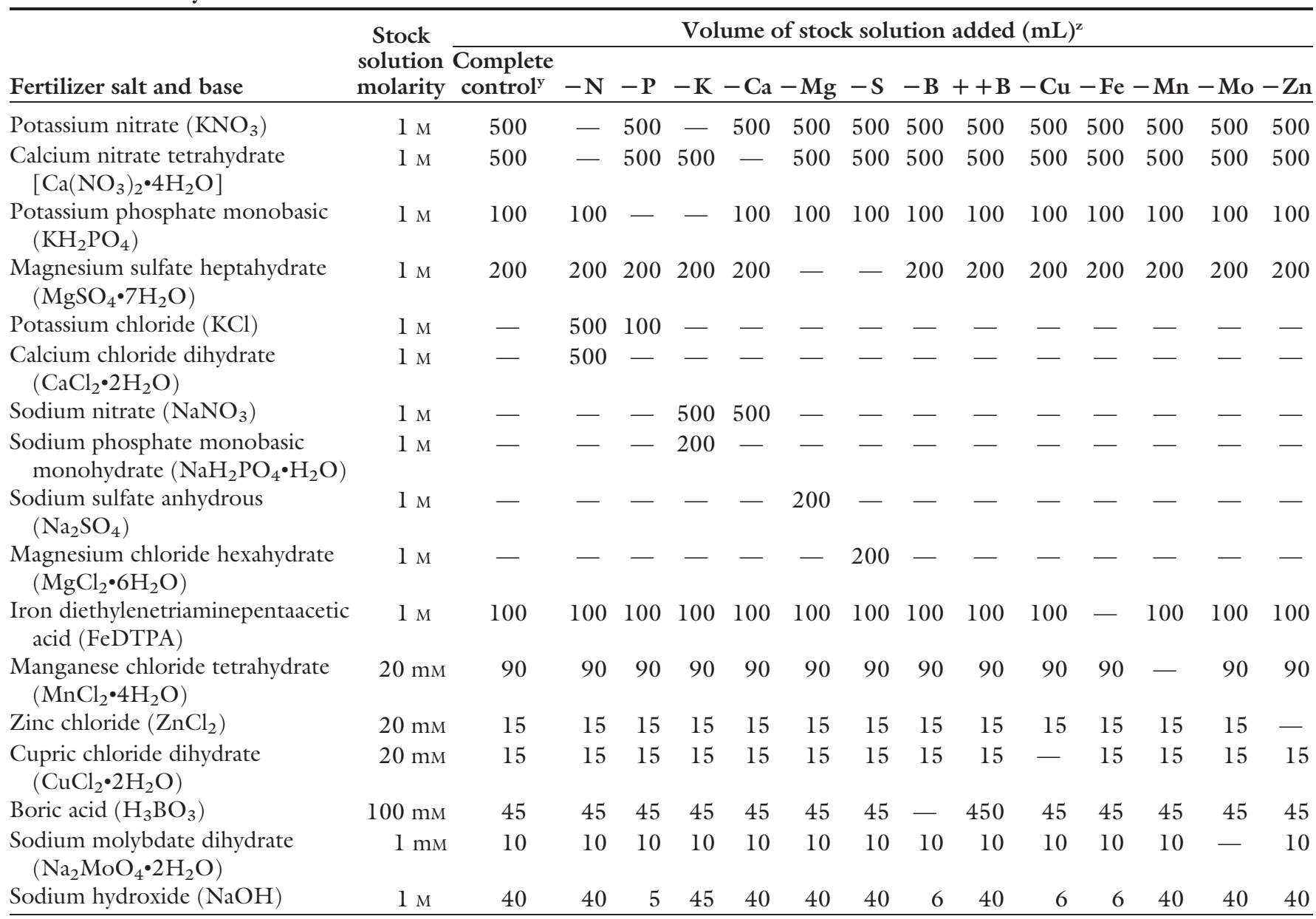

${ }^{{ }^{2}}$ Treatment formulations for nitrogen deficiency $(-\mathrm{N})$, phosphorus deficiency $(-\mathrm{P})$, potassium deficiency $(-\mathrm{K})$, calcium deficiency $(-\mathrm{Ca})$, magnesium deficiency $(-\mathrm{Mg})$, sulfur deficiency $(-S)$, boron deficiency $(-\mathrm{B})$, boron toxicity $(++\mathrm{B})$, copper deficiency $(-\mathrm{Cu})$, iron deficiency $(-\mathrm{Fe})$, manganese deficiency $(-\mathrm{Mn})$, molybdenum deficiency $(-\mathrm{Mo})$, and zinc deficiency $(-\mathrm{Zn}) ; 1 \mathrm{~mL}=0.0338 \mathrm{fl} \mathrm{oz}$.

'Recipe for the complete modified Hoagland's all-nitrate solution in which control plants were grown.

Table 2. 'Evolution' mealy-cup sage plant dry weight as affected by deficient or toxic nutrient treatments are shown in comparison with the complete control that was harvested at the time symptoms were observed.

\begin{tabular}{|c|c|c|c|c|c|c|c|c|c|c|c|c|c|}
\hline \multirow[b]{2}{*}{ Element } & \multicolumn{13}{|c|}{ Dry wt $(g)^{\mathrm{z}}$} \\
\hline & $-\mathbf{N}$ & $-P$ & $-\mathbf{K}$ & $-\mathrm{Ca}$ & $-M g$ & $-S$ & $-\mathbf{B}$ & $++B$ & $-\mathrm{Cu}$ & $-\mathrm{Fe}$ & $-M n$ & $-\mathbf{M o}^{\mathrm{y}}$ & $-\mathbf{Z n}_{\mathbf{n}}$ \\
\hline Complete control & 0.53 & 1.03 & 2.33 & 2.33 & 2.39 & 1.04 & 3.94 & 2.33 & 9.91 & 2.02 & 6.45 & 13.99 & 2.39 \\
\hline$P$ value $^{\mathrm{x}}$ & $* *$ & * & $* * *$ & $* * *$ & NS & $* *$ & NS & NS & NS & NS & NS & NS & * \\
\hline
\end{tabular}

${ }^{2}$ Treatments for nitrogen deficiency $(-\mathrm{N})$, phosphorus deficiency $(-\mathrm{P})$, potassium deficiency $(-\mathrm{K})$, calcium deficiency $(-\mathrm{Ca})$, magnesium deficiency $(-\mathrm{Mg})$, sulfur deficiency $(-S)$, boron deficiency $(-\mathrm{B})$, boron toxicity $(++\mathrm{B})$, copper deficiency $(-\mathrm{Cu})$, iron deficiency $(-\mathrm{Fe})$, manganese deficiency $(-\mathrm{Mn})$, molybdenum deficiency $(-\mathrm{Mo})$, and zinc deficiency $(-\mathrm{Zn}) ; 1 \mathrm{~g}=0.0353 \mathrm{oz}$.

'Asymptomatic treatment.

${ }^{* * * *}$, or ${ }^{* *}$ indicate statistically significant differences between sample means based on $F$ test at $P \leq 0.05, P \leq 0.01$, or $P \leq 0.001$, respectively; Ns indicates the $F$ test difference between sample means was $P>0.05$.

control and treatment tissues were significantly different when visual symptoms first appeared (Fig. 1A). Unless otherwise noted, values for tissue concentrations presented were significantly different (Table 3 ).
Nitrogen. Leaves on plants grown under $\mathrm{N}$-deficient conditions became chlorotic and had 38\% less dry weight than the control plants. The control tissue $\mathrm{N}$ concentration was $5.06 \%$, while tissue concentration from plants grown under $\mathrm{N}$-deficient conditions was $2.57 \%$. As the disorder progressed, chlorosis intensified, and the leaf margins developed a purple coloration (Fig. 1B). Lower leaf tips became necrotic. The necrotic area 

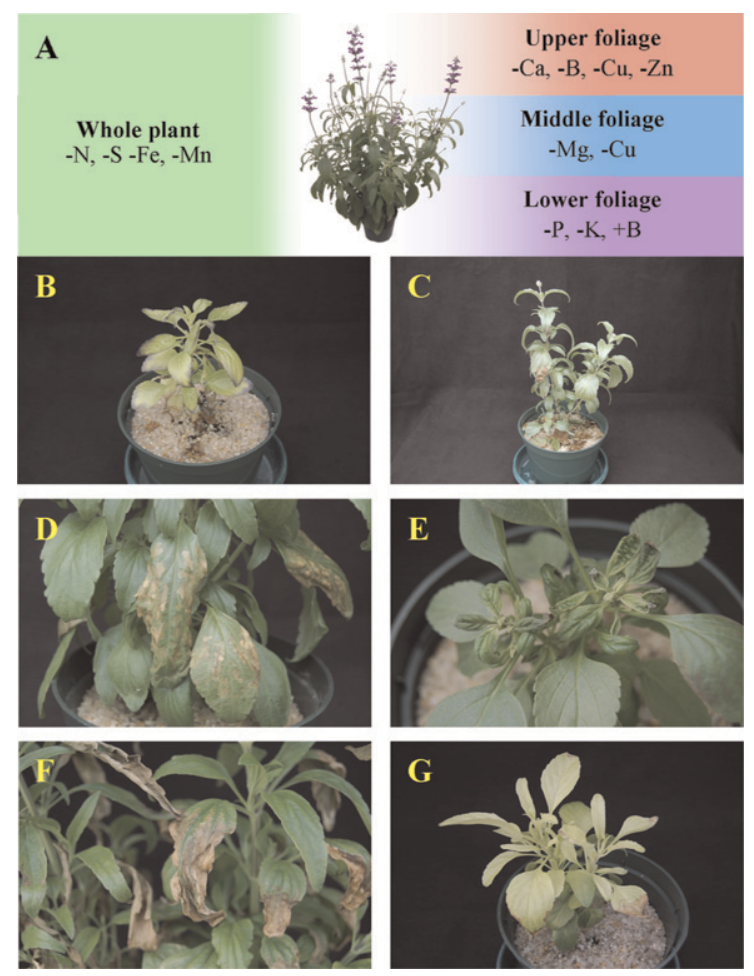

Fig. 1. (A) The location where initial symptoms were first observed on 'Evolution' mealy-cup sage plants for nitrogen deficiency $(-\mathrm{N})$, phosphorus deficiency $(-\mathrm{P})$, potassium deficiency $(-\mathrm{K})$, calcium deficiency $(-\mathrm{Ca})$, magnesium deficiency $(-\mathrm{Mg})$, sulfur deficiency $(-S)$, boron deficiency $(-B)$, boron toxicity $(++B)$, copper deficiency $(-\mathrm{Cu})$, iron deficiency $(-\mathrm{Fe})$, manganese deficiency $(-M n)$, molybdenum deficiency $(-M o)$, and zinc deficiency $(-\mathrm{Zn})$. (B) Plants grown under nitrogen deficiency exhibited chlorosis. In the advanced stage seen here, a purple coloration was observed on the leaf margins. (C) Plants grown in phosphorus-deficient conditions had less dry weight than controls and exhibited brown necrosis on the lower leaf tips; lower leaves dropped in the advanced stage. (D) Older leaves on potassium-deficient plants developed a "camouflage" necrotic pattern. (E) Upper leaves of plants grown in calcium-deficient conditions exhibited black, necrotic spots on the leaf margin and leaf curl. (F) Middle leaves of plants grown with magnesium deficiency exhibited interveinal gray-brown spots which advanced to interveinal necrosis. (G) A light green coloration manifested in sulfur-deficient plants and intensified in the middle and upper foliage.
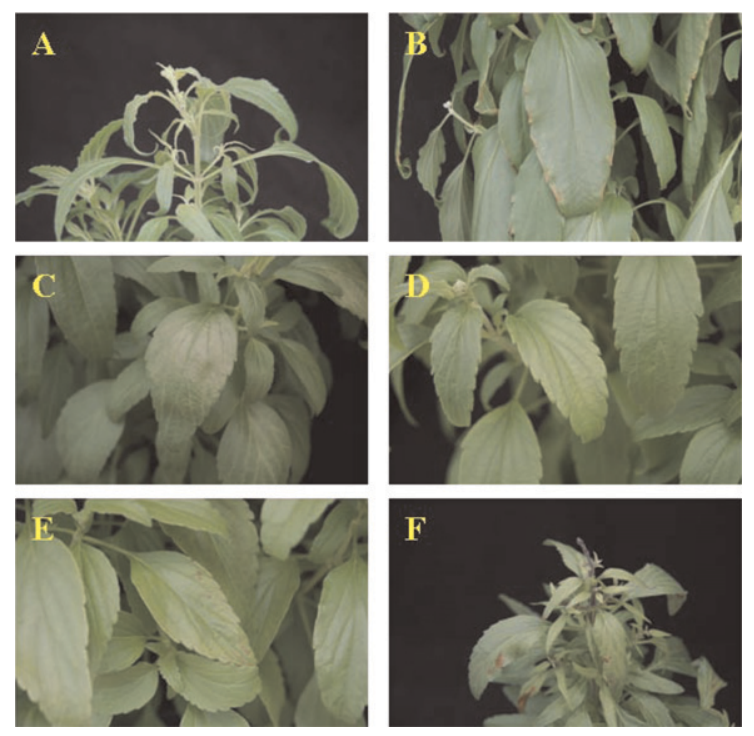

Fig. 2. (A) Upper leaves on mealy-cup sage plants growing in boron-deficient conditions developed strap-like leaves and brown spots on the leaf near the petiole. (B) Lower leaves of plants grown under boron toxicity exhibited lower-leaf, marginal necrosis. (C) On plants grown in copper-deficient conditions, green-gray coloration was observed on middle and upper leaves. (D) Plants grown under iron deficiency manifested a light green coloration. (E) Light green coloration progressed to interveinal chlorosis and brown, marginal or interveinal spotting on plants grown under the manganese-deficient regime. (F) Upper leaves on plants grown under zinc deficiency developed a light green coloration that was followed by brown necrotic spots; the inflorescence also exhibited reduced elongation and development. 


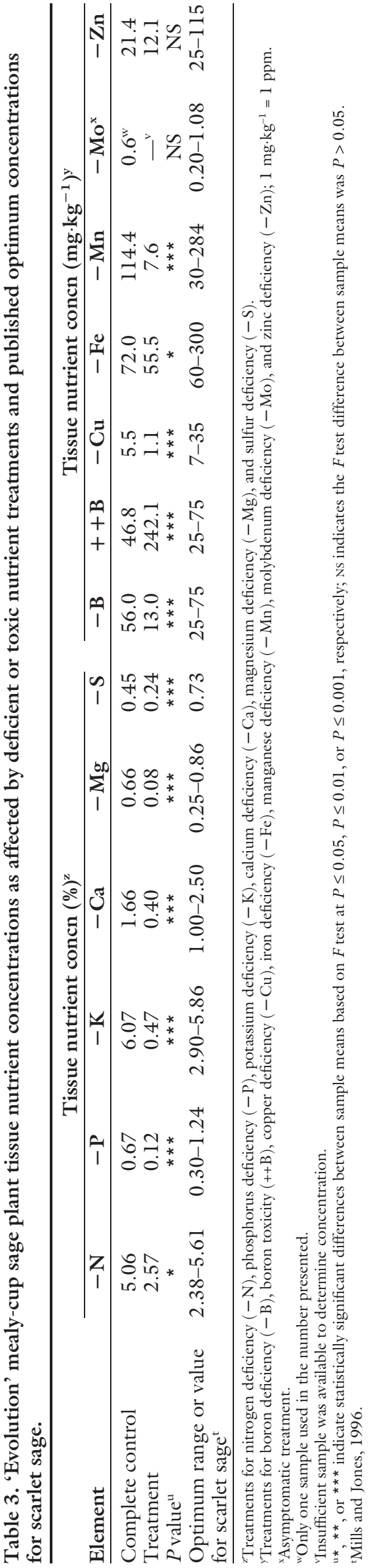

advanced inward on the leaf. In the advanced stage, the upper leaves also became necrotic.

Phosphorus. Deficiency of $\mathrm{P}$ manifested on lower leaves with brown necrotic spots appearing on the tip of the leaf (Fig. 1C). Plants grown under $\mathrm{P}$-deficient conditions had 39\% less dry weight than those receiving P. Control plants had a concentration of $0.67 \% \mathrm{P}$, and plants grown under $\mathrm{P}$-deficient conditions had a concentration of $0.12 \% \mathrm{P}$. As symptoms progressed, affected leaves abscised from the plant. Upper leaves then developed the necrotic marginal spotting.

Potassium. Plants grown without $\mathrm{K}$ had tan-brown spots appear on lower leaf margins, and K-deficient plants had 38\% less dry weight than the control plants. The $\mathrm{K}$ concentrations of control plants and plants grown under the K-deficient regime were $6.07 \%$ and $0.47 \%$, respectively. Over time, these spots increased in size and crossed veins. Middle and lower leaves then developed necrotic, mottled spotting that ranged in coloration from dark black-brown to light tangreen (Fig. 1D). The necrosis then covered the entire leaf.

Calcium. Young leaves on plants grown under Ca-deficient conditions exhibited dark necrotic spots on the leaf margin and downward curl (Fig. 1E). Plants grown without Ca had $37 \%$ less dry weight than those plants that received a complete fertilizer regime. Control plants had a Ca concentration of $1.66 \%$, while plants grown without $\mathrm{Ca}$ had a concentration of $0.40 \% \mathrm{Ca}$. Gray spots then appeared on the most recently matured leaf. The spots on both upper and middle foliage then increased in size; some leaves became fully necrotic. The apical bud became necrotic, and plant death followed.

Magnesium. Plants grown under Mg-deficient conditions first exhibited gray-brown spots on the interveinal regions of middle leaves. A significant difference was not observed between dry weights of the control plants and plants grown without Mg. Differences in $\mathrm{Mg}$ tissue concentration were significantly different with control plants containing $0.66 \% \mathrm{Mg}$ compared with $0.08 \% \mathrm{Mg}$ for the plants grown without $\mathrm{Mg}$. As the disorder progressed, the size of the spots increased (Fig. IF), and the entire leaf became necrotic. The discoloration then manifested in upper leaves, and chlorosis began to appear in lower leaves. In the advanced stage, most of the middle leaves then became fully necrotic. Chlorotic, lower leaves exhibited some brown discoloration.

Sulfur. Initially, plants grown under conditions of S deficiency developed a light green coloration. Plants exhibiting S-deficiency symptoms had $44 \%$ less dry weight than the control plants. Tissue concentrations were significantly different; control tissue was $0.45 \% \mathrm{~S}$, while the tissue of plants grown without $S$ had $0.24 \%$ $\mathrm{S}$. The light green color then intensified to chlorosis in the middle and upper leaves (Fig. 1G). Middle leaves then began to develop a marginal, brown necrosis. Upper leaves then began to develop necrosis as the middle leaves became fully necrotic.

Boron. Deficiency of B initially manifested in the young leaves. They were narrow and strap-like, and small, brown specks formed near where the leaf blade and petiole met (Fig. 2A). Dry weights between the two treatments were not significantly different. Control tissue contained $56.0 \mathrm{mg} \cdot \mathrm{kg}^{-1}$ $\mathrm{B}$, and tissue from plants grown under B-deficient conditions contained $13.0 \mathrm{mg} \cdot \mathrm{kg}^{-1} \mathrm{~B}$. As the disorder progressed, specks expanded into larger dark brown or black spots. Spotting also began to appear in the upper leaf petioles. The young foliage on lower axillary shoots began to manifest the spotting. Lower axillary shoot buds died, and then the apical bud died. In the advanced stage, lower leaves manifested interveinal chlorosis that progressed to a brown coloration. Middle and upper leaves then manifested these symptoms.

Lower leaves exhibiting brown spots along the margin was the initial symptom of B toxicity (Fig. 2B). Dry weights of the control plants and plants grown under B-toxic conditions were not significantly different, but tissue $\mathrm{B}$ concentration was. The control tissue $\mathrm{B}$ concentration was $46.8 \mathrm{mg} \cdot \mathrm{kg}^{-1}$, while the B-toxic tissue concentration was $242.1 \mathrm{mg} \cdot \mathrm{kg}^{-1}$. As the disorder progressed, the spots spread along the margin. The marginal spotting moved into the middle and upper leaves on the plant.

Copper. Plants grown under $\mathrm{Cu}$ deficiency exhibited a green-gray haze coloration that developed on 
middle and upper leaves (Fig. 2C). No significant difference was observed in plant dry weights. Control $\mathrm{Cu}$ tissue concentration was $5.5 \mathrm{mg} \cdot \mathrm{kg}^{-1}$; tissue $\mathrm{Cu}$ concentration in plants grown without $\mathrm{Cu}$ was $1.1 \mathrm{mg} \cdot \mathrm{kg}^{-1}$. Over time, the haze discoloration encompassed the entire upper leaf surface.

Iron. The development of a light green coloration in the plants was the first symptom of $\mathrm{Fe}$ deficiency (Fig. 2D). The coloration was not very apparent and would be difficult to distinguish without a control present. Dry weights of control plants and plants grown without $\mathrm{Fe}$ were not significantly different. The Fe concentration of the control plants was $72.0 \mathrm{mg} \cdot \mathrm{kg}^{-1}$, while plants grown under Fe-deficient conditions had a concentration of $55.5 \mathrm{mg} \cdot \mathrm{kg}^{-1}$. As the disorder progressed, some upper leaves developed a faint interveinal chlorosis.

MANGanese. Plants grown without $\mathrm{Mn}$ initially developed an overall light green coloration (Fig. 2E). Dry weights from the control treatment plants and plants grown under $\mathrm{Mn}$ deficient conditions were not significantly different. Control tissue had a Mn concentration of $114.4 \mathrm{mg} \cdot \mathrm{kg}^{-1}$, and plants grown under $\mathrm{Mn}$-deficient conditions contained $7.6 \mathrm{mg} \cdot \mathrm{kg}^{-1} \mathrm{Mn}$. The light green coloration intensified to interveinal chlorosis in some leaves. Brown spots then appeared on leaves throughout the plant either along the margin or in the interveinal areas; symptoms were more pronounced on the middle leaves. The spotting then progressed to leaf necrosis.

Zinc. Upper leaves on plants grown under $\mathrm{Zn}$ deficiency developed a light green coloration (Fig. 2F). Differences in $\mathrm{Zn}$ tissue concentrations were significantly different at $P=$ 0.06 . The control tissue $\mathrm{Zn}$ concentration was $21.4 \mathrm{mg} \cdot \mathrm{kg}^{-1}$, while tissue concentration in plants grown without $\mathrm{Zn}$ was $12.1 \mathrm{mg} \cdot \mathrm{kg}^{-1}$. As the disorder progressed, the upper leaves began to develop brown, necrotic spots. Also, the inflorescence elongation and development were inhibited. Axillary shoots lacked full development as well. In the advanced stage, lower leaves exhibited chlorosis.

Molybdenum. After 7 weeks of growth when the plants had reached full bloom, plants grown under Mo deficiency exhibited no visual symptoms. The experiment was ended, and these asymptomatic plants were sampled and analyzed for dry masses and tissue concentrations to determine if nonvisual differences were evident. There was no significant difference in dry weights for control plants and those grown under Mo-deficient conditions. One control sample had a Mo concentration of $0.6 \mathrm{mg} \cdot \mathrm{kg}^{-1}$, while Mo levels in all other plants including other control replicate plants and $\mathrm{Mo}^{-}$ deficient plants were below the detectable limit.

\section{Discussion}

Symptoms of N, P, K, Ca, S, and $\mathrm{Fe}$ deficiencies and $\mathrm{B}$ toxicity manifested earlier than other symptoms (data not shown); therefore, these disorders may be encountered more often by growers. The symptoms that we observed for P, K, Ca, S, B, Fe, and $\mathrm{Mn}$ deficiencies and $\mathrm{B}$ toxicity matched nutrient-disorder descriptions that were published in the literature (Barker and Pilbeam, 2007; Gibson et al., 2007). For Mo deficiency, symptoms may have not manifested because of low sensitivity of the crop to the disorder, or the plug substrate provided adequate levels.

For $\mathrm{N}, \mathrm{Mg}, \mathrm{Cu}$, and $\mathrm{Zn}$, we observed symptoms that were unique. Leaf purpling occurred on $\mathrm{N}$-deficient plants and not $\mathrm{P}$-deficient plants in maize (Zea mays) and tomato (Solanum lycopersicum) (Bould et al., 1984). This purpling of lower chlorotic leaves on $\mathrm{N}$-deficient plants was also reported for begonia (Begonia xsemperflorens-cultorum), celosia (Celosia argentea), marigold (Tagetes patula), and pansy (Viola $\times$ wittrockiana) (Gibson et al., 2007). For plants grown in $\mathrm{Mg}$ deficiency conditions, we observed an interveinal necrosis, while SePRO (2000) reported that interveinal chlorosis occurred for $\mathrm{Mg}$ deficiency. The symptoms observed for $\mathrm{Cu}$-deficient plants-green-gray coloration on the inner portion of the leaf blade-were the most unique observed in this experiment because they have not been described in the literature. Gray coloration on the tips of barley (Hordeum vulgare) and sunflower (Helianthus annuus) leaves was reported (Reuther and Labanauskas, 1973). Gibson et al. (2007) reports Cu-deficient symptoms for scarlet sage. Symptoms included $\mathrm{Cu}$-deficient plants having reduced dry weight, leaf puckering and cupping, and marginal and interveinal chlorosis that progressed to necrosis. The gray discoloration we observed was not mentioned. The lack of development of inflorescences in $\mathrm{Zn}$ deficient plants was also a unique symptom; while we observed smaller internodes, distortions of inflorescences were typically associated with $\mathrm{B}$ - and Ca-deficient conditions (Gibson et al., 2007). These unique symptoms support a species-specific approach for visual diagnosis of nutrient disorders because of the possibility of misidentification.

Necrosis was a common symptom for several of the deficiencies $(\mathrm{N}$, $\mathrm{K}, \mathrm{Ca}, \mathrm{Mg}, \mathrm{S}, \mathrm{Mn}$, and $\mathrm{Zn}$ ). Examining other symptoms would provide more evidence for a diagnosis of a specific nutritional disorder. Early spotting observed with $\mathrm{K}, \mathrm{Ca}$, and $\mathrm{Mg}$ deficiencies led to necrosis. Both Kand Ca deficiencies exhibited less chlorosis than $\mathrm{Mg}$ deficiency. Less growth was observed with Ca-deficient plants than $\mathrm{K}$ - and $\mathrm{Mg}$-deficient plants, and $\mathrm{Ca}-$ deficient plants eventually collapsed. Necrosis appeared as mottled spotting with K-deficient plants instead of interveinal necrosis observed with $\mathrm{Mg}$ deficiency. Necrosis manifested in N, $\mathrm{S}, \mathrm{Mn}$, and $\mathrm{Zn}$ deficiencies after other symptoms appeared. Plants grown in $\mathrm{N}$-deficient conditions exhibited chlorosis with purple coloration before necrosis manifested on lower leaf tips. In S-deficient plants, chlorosis manifested before necrosis. Plants grown in Mn-deficient conditions exhibited significant growth before they first manifested chlorosis that then developed into necrosis. For $\mathrm{Zn}$ deficiency, necrotic spots developed on upper leaves with inflorescences that lacked full development.

In the macronutrient deficiency treatments, $\mathrm{Na}$ or $\mathrm{Cl}$ was used as the counterion. The highest level of $\mathrm{Cl}$ in solution was $531 \mathrm{mg} \cdot \mathrm{kg}^{-1}$ for the $\mathrm{N}$-deficiency treatment, which was within the sufficiency range of $20-1500 \mathrm{mg} \cdot \mathrm{kg}^{-1}$ reported by Jones (2000); further, Jones (2000) stated that $\mathrm{Cl}$ is in excess after reaching levels of $5000 \mathrm{mg} \cdot \mathrm{kg}^{-1}$. For $\mathrm{Na}$, we calculated a sodium adsorption ratio (SAR) value of 0.67 for the solution; values $<3$ are considered ideal, and no negative impact is expected with $<6$ (Peterson, 1996). Therefore, it was unlikely that their elevated levels induced a $\mathrm{Na}$ 
or $\mathrm{Cl}$ toxicity that confounded the results.

When the control and deficient treatment concentrations were compared with Mills and Jones (1996) optimum ranges and values (Table 3), for the control plants, eight concentration averages $(\mathrm{N}, \mathrm{P}, \mathrm{Ca}$, $\mathrm{Mg}, \mathrm{B}, \mathrm{Fe}, \mathrm{Mn}$, and Mo) fell within those reported values, three concentration averages $(\mathrm{S}, \mathrm{Cu}$, and $\mathrm{Zn})$ were below the values, and the $\mathrm{K}$ concentration average was above the values. All of the deficient treatment values we reported except for $\mathrm{N}$, which was in the lower end of their optimum range, were lower than those reported by Mills and Jones (1996). Our values provide guidelines for interpreting the lower threshold tissue concentrations, and the information reported will be helpful to growers diagnosing mealy-cup sage and other sage species nutritional problems.

\section{Literature cited}

Armitage, A.M. 2001. Armitage's manual of annuals, biennials, and half-hardy perennials. Timber Press, Portland, OR.
Armitage, A., T. Dudek, S. Gortsema, and B. Knox. 1994. Growing basics for salvia. Professional Plant Growers Assn. News 25(5):17.

Barker, A.V. and D.J. Pilbeam. 2007. Handbook of plant nutrition. CRC Press, Boca Raton, FL.

Barnes, J. 2010. Characterization of nutrient disorders in floriculture crops. North Carolina State Univ., Raleigh, MS Thesis.

Bould, C., E.J. Hewitt, and P. Needham. 1984. Diagnosis of mineral disorders in plants. Vol. 1. Chemical Publishing, New York.

Briskin, D.P. and A. Bloom. 2010. Mineral nutrition, p. 107-130. In: L. Taiz and E. Zeiger (eds.). Plant physiology. 5 th ed. Sinauer Assoc., Sunderland, MA.

Dole, J.M. and H.F. Wilkins. 2005. Floriculture principles and species. 2nd ed. Pearson-Prentice Hall, Upper Saddle River, NJ.

Dreistadt, S.H. 2001. Integrated pest management for floriculture and nurseries. Univ. of California Publ. 3402.

Gibson, J.L., D.S. Pitchay, A.L. WilliamsRhodes, B.E. Whipker, P.V. Nelson, and
J.M. Dole. 2007. Nutrient deficiencies in bedding plants. Ball Publishing, Batavia, IL.

Hoagland, R.J. and D.I. Arnon. 1950. The water-culture method for growing plants without soil. California Agr. Expt. Sta. Circ. 347 (revised ed.).

Jones, J.B., Jr. 2000. Hydroponics: A practical guide for the soilless grower. St. Lucie Press, Boca Raton, FL.

Mills, H.A. and J.B. Jones, Jr. 1996. Plant analysis handbook II. Micromacro Publishing, Athens, GA.

Nelson, P. 2012. Greenhouse operation and management. 7th ed. Prentice Hall, Upper Saddle River, NJ.

Peterson, F.H. 1996. Water testing and interpretation, p. 31-49. In: D.W. Reed (ed.). Water, media, and nutrition for greenhouse crops. Ball Publishing, Batavia, IL.

Reuther, W. and C.K. Labanauskas. 1973. Copper, p. 157-179. In: H.D. Chapman (ed.). Diagnostic criteria for plants and soils. Quality Printing Co., Abilene, TX.

SePRO. 2000. Salvia (sage): Cultural tips \& guidelines. SePRO Corp. Carmel, IN. 